\title{
Investigating submerged morphologies by means of the low- budget "GeoDive" method (high resolution for detailed 3D reconstruction and related measurements)
}

\author{
Giovanni Gaglianone, Jacopo Crognale, Carlo Esposito \\ Department of Earth Sciences, Sapienza University of Rome, Rome, Italy
}

\begin{abstract}
Geophysical methods allow to collect geological data on lake and sea bottoms and characterize large areas, even at high depths, but with high costs. Moreover, the most widespread acquisition methods for morpho-bathymetric survey and the related instruments used are almost always ship-, ROV- or AUV-based and consequently they require high budgets.

It is known that shallow waters can represent a limit for certain vessels and techniques, preventing the acquisition in the shoreface zone. To overcome the limits, i.e. to survey with high accuracy nearshore shallow waters with a low budget, we tested and tuned the "GeoDive" method that allowed us to survey two test sites, featured by the presence of "block fields" (i.e., accumulations of huge blocks and boulders of gravitational origin) under shallow waters.

The "GeoDive" method allowed us to map the submerged morphologies and to acquire high-resolution optical images for further photogrammetric processing. The latter was fundamental to obtain 3D high-resolution models, also with conditions of low visibility. An Action Sport Cam with high definition resolution has been used for video acquisition, in addition to the equipment used during scientific diving.

By coupling the processing of underwater-acquired data with the direct surveys performed by underwater SCUBA operators, it was possible to perform some morphological and sedimentological measurements and observations on the experimental targets, with the help of suitable markers.
\end{abstract}

Section: RESEARCH PAPER

Keywords: geological survey; underwater photogrammetry; scientific diver; SCUBA; shallow waters; 3D HD reconstruction

Citation: Giovanni Gaglianone, Jacopo Crognale, Carlo Esposito, Investigating submerged morphologies by means of the low-budget “GeoDive” method (high resolution for detailed 3D reconstruction and related measurements), Acta IMEKO, vol. 7, no. 2, article 9, June 2018, identifier: IMEKO-ACTA-07 (2018)-02-09

Section Editor: Fabio Leccese, Università degli Studi di Roma Tre, Italy

Received January 19, 2018; In final form March 27, 2018; Published June 2018

Copyright: (C) 2018 IMEKO. This is an open-access article distributed under the terms of the Creative Commons Attribution 3.0 License, which permits unrestricted use, distribution, and reproduction in any medium, provided the original author and source are credited

Funding: This work has been partly funded by the research project "Influence of geothermal systems and related thermal regime variations on the onset and development of large slope instabilities in the island of Ischia" (Sapienza University of Rome, project code C26A15FH3L, responsible Carlo Esposito)

Corresponding author: Giovanni Gaglianone, e-mail: giovanni.gaglianone@uniroma1.it

\section{INTRODUCTION}

The origin of this work is due to the desire to survey and document in detail a submerged morphology detected in the Albano Lake (Latium, Central Italy) using multiple beam techniques in bathymetric surveys [1]-[5]. Hypotheses in terms of genesis of such a morphology have been already proposed, but with no support from direct observations as well as detailed measurements, neither in its shallowest part.

One of the main goals of this work has been to test the possibility of detailed surveys and measurements by means of low-budget instrumentations and activities, such as SCUBA (Self Contained Underwater Breathing Apparatus) diving to support 3D reconstructions, exploiting the Structure from Motion (SfM), high accuracy technique and using an Action Sport Cam (ASC) with high definition resolution (HD). The potential of the proposed method does not rely only on the cost-effectiveness but also on the possibility to fill some potential gap of some vessel-based geophysical surveys such as 
those of the reachability of shallow waters. This paper explains the processing steps of the method that we have named "GeoDive", by analogy with the praiseworthy geomorphological research project "Geoswim" carried out at sea using snorkeling surface techniques [6]-[8]. For this aim two case studies where the GeoDive method has been tested and applied are presented.

The first part of the work, performed in cold (winter, 9$10^{\circ} \mathrm{C}$ ), and often with low visibility, fresh water of volcanic Albano Lake [9], was followed, in a similar way, in warm shallow coastal marine water (summer, $25^{\circ} \mathrm{C}$ ), to test the method with better environmental conditions and for applying some different setting in shooting configuration, considering the experience so far accumulated. For this purpose, has been detected, on a smaller scale, a similar confined submerged morphology in an embayed pocket beach [10], [11] along the Maratea coast (Tyrrhenian Sea, Basilicata, Southern Italy).

\section{GEOLOGICAL AND GEOMORPHOLOGICAL SETTING}

\subsection{The Albano Lake}

The Albano Lake (Figure 1) is located about $20 \mathrm{~km} \mathrm{SE}$ of Rome (Italy), $287 \mathrm{~m}$ above sea level, and with a depth of 167 meters is the deepest crater lake in Italy; it fills a large, multiple maar depression, which represents one of the youngest craters of the Colli Albani volcano [12], formed following the most recent activity of the Final Hydromagmatic phase [13].

The Colli Albani volcano is part of the high-K Roman Comagmatic Province (Italy), characterized by the superposition of several volcanic episodes, and related edifices, having significant differences in eruptive style, eruption rate and chemistry [14].

The Colli Albani volcano compositions are dominantly tephritic to K-foiditic [15].

With reference to the Albano Lake it is possible to briefly sketch the main geological features and the gravity-induced morphologies featuring the inner slopes.

The geological setting is featured by a sequence of both basaltic rocks and stiff tuffs, the latter being predominant. Most of the outcrops show a reverse-slope attitude of the layers, but dip-slope layers are locally present. In the first case the gravityinduced processes, very common over the whole inner slope [2], [16] are featured by rock-fall and topples while rock slides

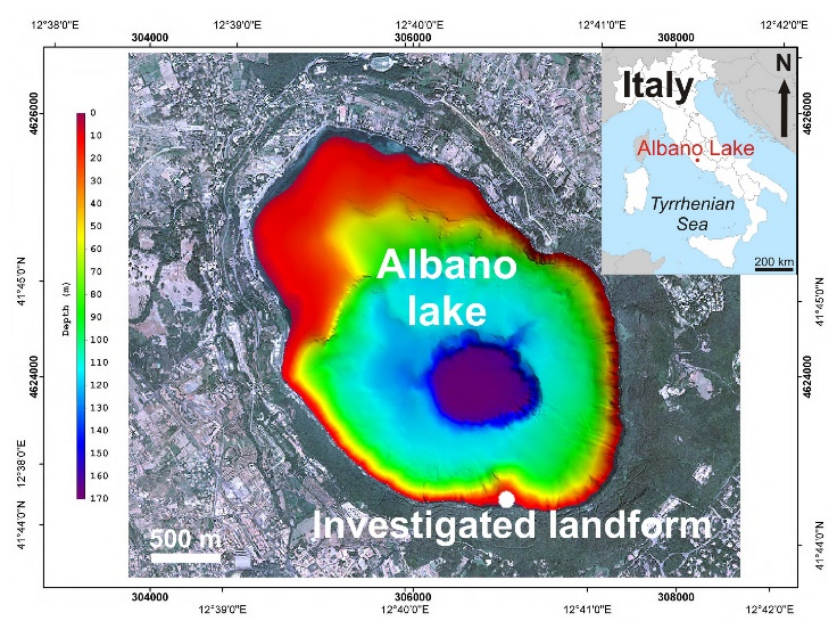

Figure 1. The Albano Lake, with the bathymetric range shown as colours shades (modified from [5]). can occur in the dip-slope areas. Furthermore, the tuffs are affected by significant weathering processes that cause the formation of up to $2 \mathrm{~m}$ thick eluvial deposits, which are often involved in debris-flow processes.

Gravity-induced morphologies in the submerged slopes have been recognized (Figure 2), among which subaqueous landslide scars and block fields [2], [4]. The latter can be usually considered as the subaqueous continuation of landslides detached from the subaerial slopes. In particular, the Albano Lake floor shows positive convex landforms considered as landslide debris accumulations, with shape and dimensions largely variable, many of which downslope of a detachment area; also, landslide channels and outrunner blocks are present [2], [4].

\subsection{Maratea coast}

The Basilicata Tyrrhenian coast (Figure 3) is $20 \mathrm{Km}$ long and is totally located in the municipality of Maratea, the only municipality of the Basilicata Region (Southern Italy) overlooking the Tyrrhenian Sea. The coast is characterized from the geomorphological point of view by a sequence of promontories, high cliffs and shore platforms, intercalated to a series of gravel pocket beaches [17], [18]. Sandy-gravel deposits that lie along the Tyrrhenian coast of Basilicata are interpreted as relict sediments [19].

The numerous faults in this area are the result of Plio-

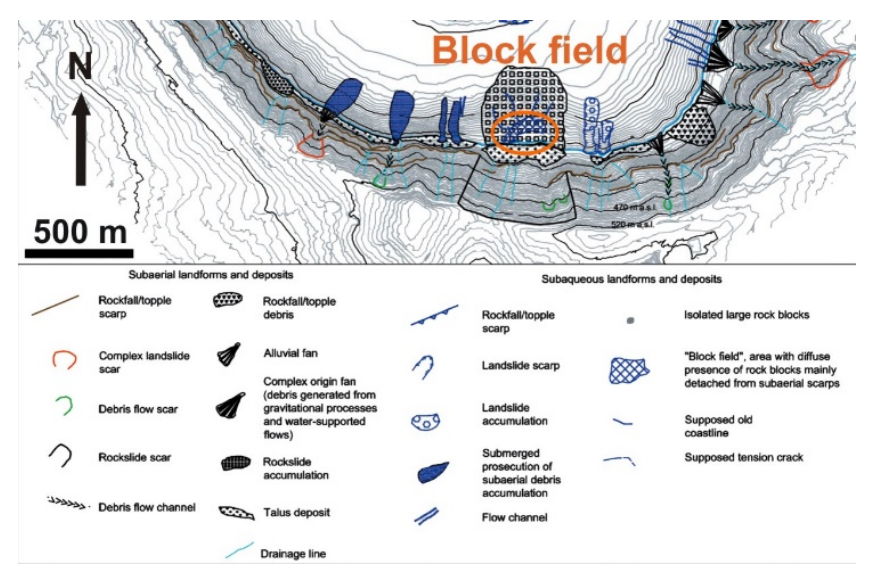

Figure 2. Excerpt from inventory map of gravity-induced landforms, modified from [2]: investigated block field (orange ellipsis) of the southernmost sector of the Albano Lake crater.

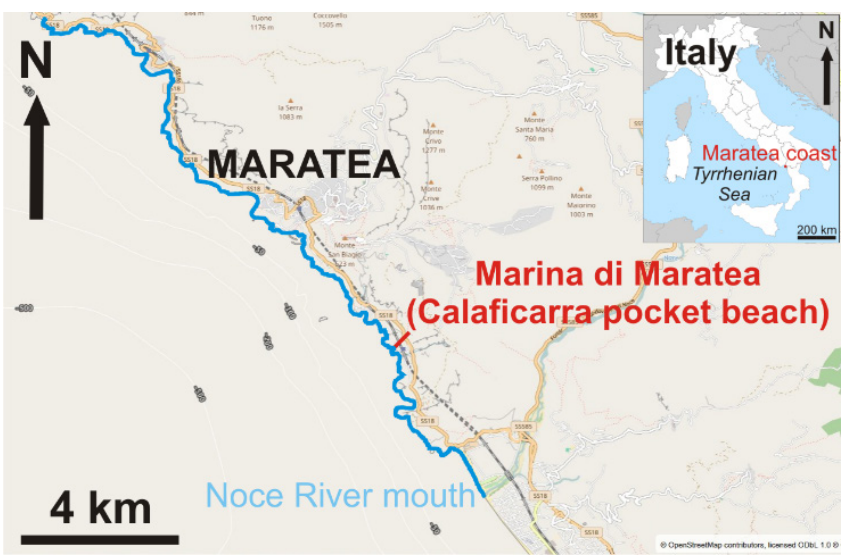

Figure 3. Basilicata Tyrrhenian coast of Maratea (cyan line) and Calaficarra pocket beach (from EMODnet Portal for Bathymetry, modified). 
Quaternary tectonic activity; the coastal slopes present many vertical or sub-vertical rock faces and many systems of discontinuities [20].

Often, the submerged morphologies have a generally quadrangular shape, highlighting the structural control of edging and transversal faults, that have eased the entry of the sea and the relative mechanical action of the water. In some cases, along the edges of the slopes of the coastal shelves, are found collapsing deposits, debris accumulations and accumulation of large blocks [19].

Along the southernmost sector of the coast (from Maratea, to the North, to the Noce River, to the South) the coastal morpho-structures are almost exclusively composed by dolomite sequences belonging to the Bulgheria-Verbicaro units of the Campano-Lucana Platform [21], [22]. The slopes facing the sea, in this area, follow a fault scarp accompanied by the production of detrital deposits [20].

The Maratea coastal area suffers of periodic rockfall events, given the nature of the outcrops present there, which impact along the Maratea SS18 coastal road, a main strategic road in a touristic area [20].

Behind the coastlines, the area of Maratea Valley shows large-scale gravitational phenomena and sagging type morphology [23]-[25].

\subsection{The block field of Albano Lake}

The investigated block field is located along the southernmost sector of the lake (Figure 2) and its origin is related to subaerial rock fall processes [2]; the underwater survey concerned its right side, as its area is too wide to be fully detected in this context (Figure 2 and Figure 5). In this area, the block field start directly from the shoreline; the observed blocks, in the bathymetric range 0-13 meters of water depth (from now onwards mwd) have dimensions between decimeters and meters and are all in touch with each other (Figure 6). Immediately below 13-15 mwd the blocks are no longer in contact; indeed, they are distant from each other, always large (metric dimensions) and increasingly isolated when the depth increases; they almost disappear below 15-18 mwd, where they become sporadic, but however present, until about $20 \mathrm{mwd}$. In these bathymetric range prevail the finest sediments: from some preliminary analyses carried out between 5 and $12 \mathrm{mwd}$, the sediment is formed essentially from sand, with more or less gravel, but always with little mud amount.

\subsection{The block field of Calaficarra pocket beach}

The Calaficarra pocket beach (Figure 3 and Figure 7) is located along the southernmost sector of the Maratea coast, in the locality of Marina di Maratea; the length of her shoreline is less than fifty meters and the sediments of both emerged and submerged beach are almost exclusively made up of gravel. The bottom of the submerged beach shows two distinct series of bedforms, the first, shallower, between 2-4 mwd and the second, deeper, starting from $7 \mathrm{mwd}$. In the bathymetric range between 4 and 7 mwd a belt of boulders as a block field (Figure 8 ), surrounded by a bed of pebbles and cobbles, separates the two series of bedforms [11]. The blocks, with apparent chaotic disposition, have dimensions between decimeters and meters, such as those observed in the Albano Lake, without reaching its larger size.

The block field was surveyed and simultaneously its outer perimeter was defined using GPS, then mapped (red line on Figure 7); the straight line marked by letters A, B and C, N-S oriented and 30 meters long, indicates the position on the bottom of the used measure tape used during the video

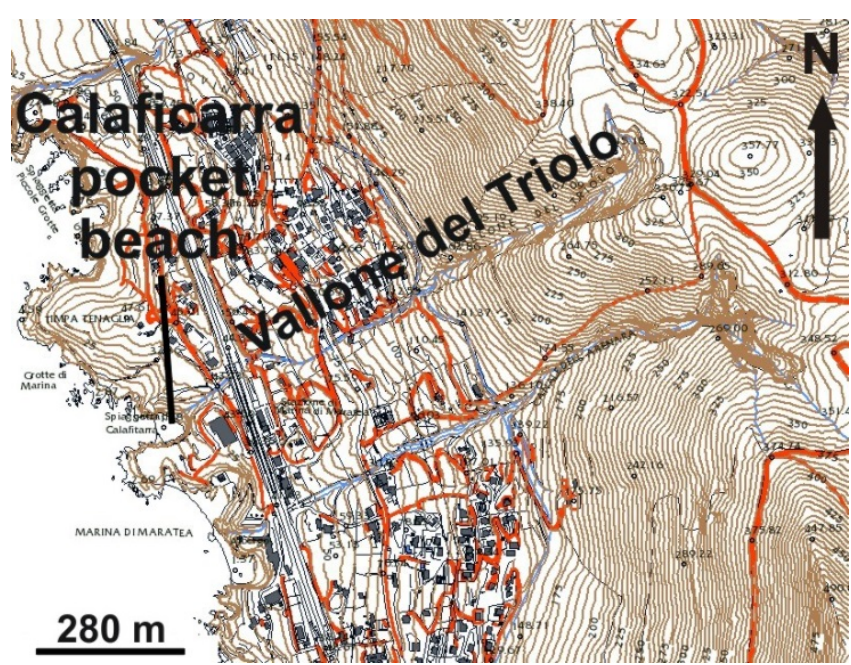

Figure 4. Calaficarra pocket beach and Vallone del Triolo location; excerpt from "Cartografia Tecnica Regionale Numerica (CTRN) della Regione Basilicata in scala 1:5000", modified (from Basilicata PODIS web portal: http://basilicata.podis.it).

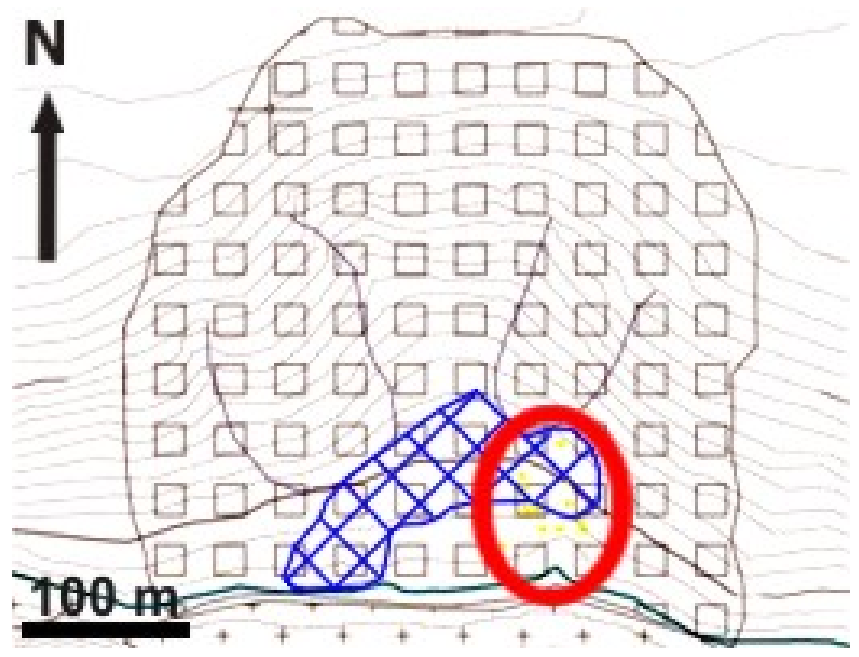

Figure 5. Albano Lake: surveyed area (red ellipse) which includes the right side of the block field (blue grid); the yellow dots show the GPS detected points (modified from [2]).

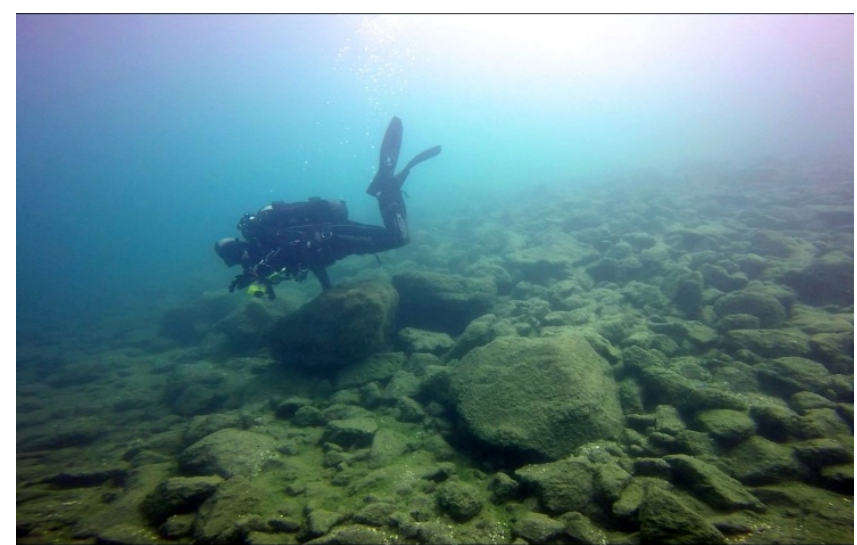

Figure 6. View of the block field on the bottom of the Albano Lake (about 7$8 \mathrm{mwd})$. 


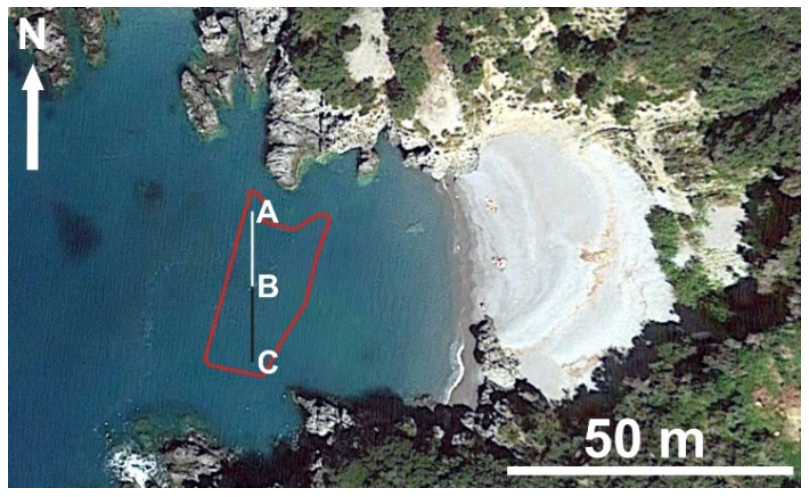

Figure 7. Calaficarra pocket beach: block field external perimeter (red line) and straight-line indicating the measure tape placed on the bottom.

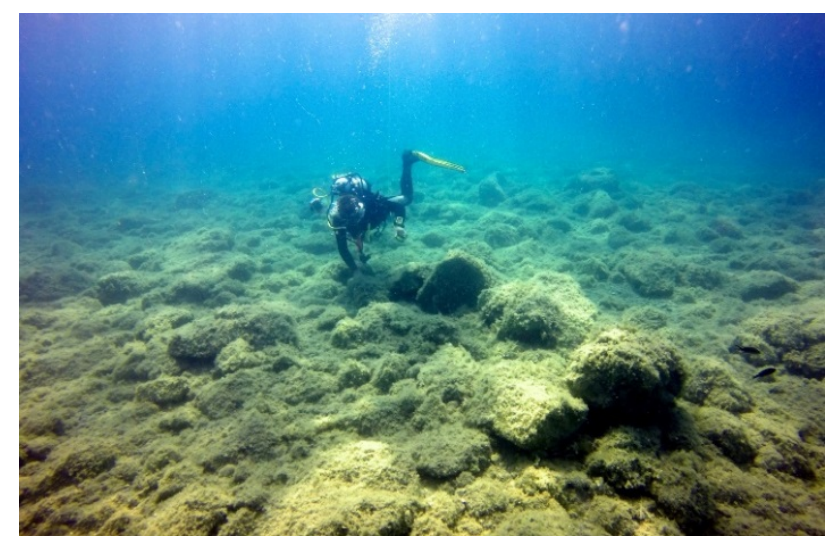

Figure 8. View of the block field of the Calaficarra pocket beach to 5-6 mwd (modified from [11]).

acquired area (Figure 8). The shape and position of the block field, adjoining the emerging shore platform, almost as a continuation, seems to indicate the genesis for collapse and accumulation in place with minimal dislocation of the blocks, in accordance with what is stated in the above-mentioned literature regarding emerging and submerged morphologies. However, it is planned to analyse the exact petrological origin of the blocks, to assess the most probable source area. The block field can be in fact interpreted as the result of rockfalls occurring along the coastal shore platform but also as a remnant of an alluvial apron fed by the Vallone Triolo catchment and chute (Figure 4), even if it appears to be dormant based on morphological evidence, also due to the water drainage related to anthropization in the upper slope.

\section{MATERIALS AND METHODS}

\subsection{Data acquisition}

A series of ten scientific dives were carried out with SCUBA equipment using standard air (EAN 21) as respiratory gas, from February to August 2017 (Table 1).

Some preliminary and exploratory dives were performed in the Albano Lake for detecting and delimiting the area of interest, followed by the other operational dives, that allowed us to characterize the substrate from the geomorphological point of view (underwater geological survey). Furthermore, it was possible to perform other scheduled "logistic" activities to support the $3 \mathrm{D}$ reconstruction, such as the positioning at the bottom of a reference grid (ribbon stripes) consisting of eight squares having sides of length ten meters, with fifteen
Table 1. Scheduled and performed activities carried out during the scientific dives (from February to August 2017).

\begin{tabular}{|c|c|c|}
\hline Dive & Site & $\begin{array}{c}\text { Activities } \\
\end{array}$ \\
\hline $\begin{array}{c}1-2 \\
\text { (preliminary } \\
\text { dives) }\end{array}$ & $\begin{array}{c}\text { Albano Lake } \\
\text { (February 2017) }\end{array}$ & $\begin{array}{l}\text { Detection of the area to delimit; } \\
\text { preliminary geomorphological survey }\end{array}$ \\
\hline $3-4$ & $\begin{array}{l}\text { Albano Lake } \\
\text { (February 2017) }\end{array}$ & $\begin{array}{l}\text { Positioning at the bottom of the } \\
\text { reference grid; geomorphological } \\
\text { survey }\end{array}$ \\
\hline $5-6$ & $\begin{array}{l}\text { Albano Lake } \\
\text { (March 2017) }\end{array}$ & $\begin{array}{c}\text { Video acquisition (several } \\
\text { configurations) }\end{array}$ \\
\hline 7 & $\begin{array}{l}\text { Albano Lake } \\
\text { (April 2017) }\end{array}$ & $\begin{array}{l}\text { GPS acquisitions of detected points } \\
\text { (artificial markers and some peculiar } \\
\text { boulder like natural marker) }\end{array}$ \\
\hline 8 & $\begin{array}{l}\text { Albano Lake } \\
\text { (June 2017) }\end{array}$ & $\begin{array}{c}\text { Some block measurement; sediment } \\
\text { sampling }\end{array}$ \\
\hline 9 & $\begin{array}{l}\text { Maratea - } \\
\text { Calaficarra } \\
\text { pocket beach } \\
\text { (August 2017) }\end{array}$ & $\begin{array}{l}\text { Detection of the area to delimit; } \\
\text { geomorphological survey; positioning at } \\
\text { the bottom of the reference markers; } \\
\text { video acquisition (two configurations) }\end{array}$ \\
\hline 10 & $\begin{array}{l}\text { Maratea - } \\
\text { Calaficarra } \\
\text { pocket beach } \\
\text { (August 2017) }\end{array}$ & $\begin{array}{c}\text { GPS acquisitions of detected points } \\
\text { (artificial markers and block field } \\
\text { external perimeter) }\end{array}$ \\
\hline
\end{tabular}

numbered vertices (numbered bricks) and covering a total area of eight hundred square meters. These artificial markers of known position and size (Figure 9) were required both for the video acquisition and for the subsequent correct positioning in the three-dimensional virtual space of the 3D reconstructed model and scaling it correctly; also the singularity of some boulders, of peculiar shape and size (Figure 10), have been used

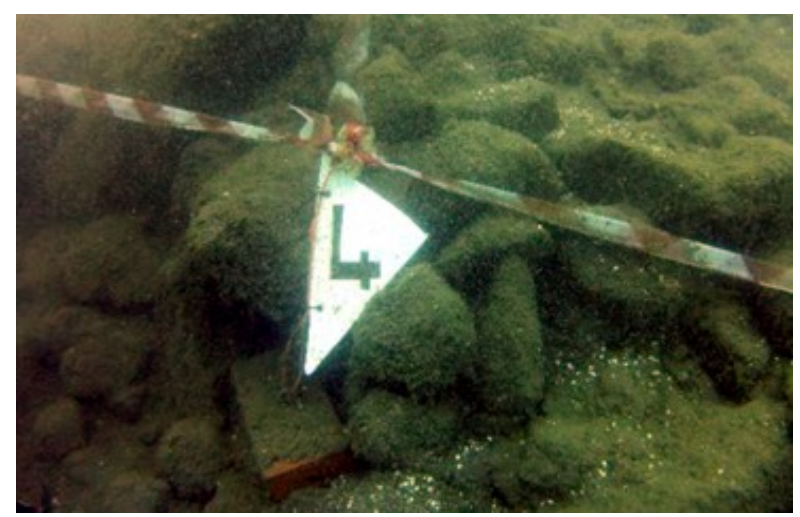

Figure 9. Artificial markers: brick No. 4 and part of ribbon forming a grid (modified from [9]).

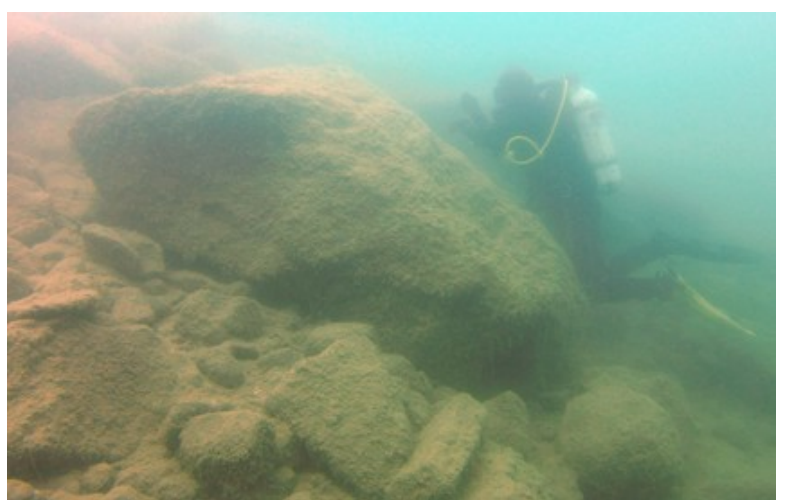

Figure 10. Albano Lake: a boulder of peculiar shape and size, used on as natural markers (13 $\mathrm{mwd})$. 
on both sites as natural markers like peculiar spot used for the final 3D reconstruction.

An ASC GoPro ${ }^{\circledR}$ Hero 4 Black Edition able to record video and image up to $4 \mathrm{~K}$ video resolution (3840x2160 pixels) has been used for video acquisition to map the submerged morphologies and to acquire high-resolution optical images for further photogrammetric processing. This family of ACS have been successfully tested already in subaerial applications [26], but their use is now widespread even in underwater scientific works [27].

The camera was set using HD resolution (1920x1080 pixels), Narrow FOV (field of view), which corresponds to a focal length equivalent of $34.4 \mathrm{~mm}$, and an acquisition frequency (frame rates) of $50 \mathrm{fps}$ (frames per second), with a resultant pixel size of $0.26 \mathrm{~mm}$.

The most efficient shooting mode for capturing a video, intended for photogrammetric decomposition, and for the three-dimensional reconstruction of a large area, is azimuthal to the subject. Slightest variations of the shooting angle, on the recovery plane, relative to the vertical direction (few degrees, at most 10 degrees per side) were made, for helping the reconstruction and allowing to cover a more complete and accurate shooting range.

The video acquisition in the Albano Lake, relative to a reference square $\left(10 \times 10 \mathrm{~m}, 100 \mathrm{~m}^{2}\right)$ was made by following a single underwater track, using the grid reference ribbons to delimit routes. Starting from one of the deepest vertex of the square and performing transects parallel to the isobaths, each time that one of the lateral ribbons was reached (orthogonal to the isobaths, at the opposite edge), it went ascending for a while, following the ribbon, to then carry out the next part of the journey (parallel to the transect just made, but in the opposite direction) and therefore have the maximum overlap between the videos relative to two consecutive transects. This greater number of parallel transects performed allow to obtain the correct minimum side lap of $20 \%$.

The routes carried out have been done trying to keep constant the depth of the framed bottom and the distance between the scuba operator and the bottom (use of depth gauge and a suitable spacer built on the principle of lead wire, at sight), and finally, given the short-traveled distances, the straightness of the route (compass use).

After several tests performed in Albano Lake, the best distance between the scuba operator and the bottom was fixed in $50-70 \mathrm{~cm}$, while at Maratea a nearly double distance was tested $(1-1,5 \mathrm{~m})$, given the best visibility conditions at sea. At these distances also occurs that the distortion caused by the lens of the ASC was almost zero, so it was not necessary to compensate for this defect in post-production.

Some surveys test was performed in the lake at greater distances from the bottom $(2-3 \mathrm{~m})$ but due the low visibility found, led us to not be able to continue, not only because in the video acquisition the bottom was almost not visible, but, and not secondarily, for security reasons, given the impossibility of following the references and being able to perform the correct underwater navigation.

A small distance to the bottom has been substantially maintained even at sea, despite significantly higher visibility, also to maintain a high ground resolution of the final product for a comparison of the reconstructed 3D models.

it should be highlighted, instead, that having limited the distance from the bottom has besides allowed to make video acquisition that have provided usable images, which have not even required a phase of cleaning and improvement (enhancement) that is usually done in post-production in order to restore the quality of video frames [27], [28]; on the contrary, given the environmental conditions found in the lake, if the video acquisitions were taken from a greater distance, no images would be available, even after trying to improve them.

Finally, the image enhancement was not necessary also due to the high number of frames extracted have allowed a careful overlap between them on each single element (block), allowing the software to align the images and build a detailed threedimensional reconstruction.

As reported in similar study cases [27], but also in many scientific papers referred to other research areas [28]-[33], before performing a $3 \mathrm{D}$ reconstruction, a camera calibration is required, to correct the geometric parameters of the camera and the lens distortion; for this purpose, it is mandatory taking into account the camera propriety and the setting conditions used, mentioned above. For the camera calibration process has been used the internal calibration tool from the main menu of the used software that performs the photogrammetric processing of digital images (Agisoft PhotoScan). The tool allows to enter parameters which camera type (frame), pixel size and focal length.

The short distance between the lens and the framed area, the resultant equivalent focal length and the small size of the developed models (called "sub-models", as explained below) have allowed to drastically reduce the distortion of the final three-dimensional product, as verified during the test phase. The model was verified and validated by comparing the wellknown dimensions of the reference objects placed in situ (artificial markers: ribbons and bricks) with their resultant dimensions into the sub-models. For these reasons, jointly with the difficult working conditions found during the performed dives in the Albano Lake, which led us to minimize the operations to be carried out, we deliberately did not make any further types of external calibration.

Several and necessary GPS acquisitions of artificial markers have been made by two operators; the first on the bottom and the second on the surface; a dive buoy with its related cable held upright by using a ballasted reel, considering the low depths, it was enough to mark the bottom points of interest, according to specifics signals sent [34].

No auxiliary light sources were needed during video shooting; indeed, it was verified that the use of artificial lighting, which often does not uniformly cover the framed field, makes video shooting less clear in the subsequent processing phase. In low visibility conditions, finally, the lighting is totally counterproductive, creating diffusion phenomena around the particles present in suspension in the water. Similarly, no colored filters were installed in front of the camera lens, because it has been privileged the amount of light captured by the camera compared to the improvements of the video, leaving the shot made as neutral as possible (the very widely used frontal colored filters, orange for the sea and pink/purple for the fresh water are used to improve color rendering and making the shots a little more contrasted, but they subtract light).

In the Albano Lake, for characterizing the texture of the sediments present among the boulders, three samples of superficial sediment were collected by SCUBA diving along downdip transects, alongside the external side of the grid, towards the west, between 5 and 12 mwd.

The samples were split in sub-samples weighing about $100 \mathrm{~g}$, one of which washed first in a water solution of hydrogen 
peroxide (25\% vol.), then in distilled water and cleaned of all organic residues. After washing, the samples were dried at $40{ }^{\circ} \mathrm{C}$ and subsequently weighed, dispersed again in the water, split by the wet process using a sieve with mesh $63 \mu \mathrm{m}$ in two aliquots, sand and gravel $(>63 \mu \mathrm{m})$ and mud $(<63 \mu \mathrm{m})$. Granulometric analysis of sediments were performed separately by dry sieving for sand and gravel fraction and by wet laserdiffraction analyses for the mud fraction, then were reported as entire single frequency distributions for define the sediment textures of the samples (gravel, sand, silt and clay percentages, mean size, sorting, skewness and kurtosis) [35].

\subsection{Data processing}

Three-dimensional reconstruction of the block fields with SfM techniques starts with the factorization in photo frames of the acquired file video; the Free Video to JPG Converter software was used for extract frames from video files. Images available are not used all, they are enough 10 out of 50 for each second for allow the overlay of $60 \%$ between a frame and the next, considered a mandatory factor to be guaranteed the achievement of the 3D reconstruction, made with Agisoft PhotoScan software.

As a rule, the generation of a three-dimensional model passes for three subsequent phases: a Sparse Cloud resulting from the alignment of the frames, a reworked Dense Cloud (both Points Clouds) and a Mesh, which returns the surface reconstruction of the objects resulting from the interpolation of the points ensembles. Another useful step to apply in SfM method is the texturization of the meshed model in real colors, derived from the frames used; this can give a most real product of the analyzed area.

The higher is the number of points provided by the Dense Cloud, the smaller is the error contained in the relative Mesh, and smaller are too the chances of having "bugs" in the resulting surface (Figure 11).

Sub-models Mesh deriving from 100 frames was made, using the automatic catching markers; the union of two consecutive sub-models was performed with the manual search of markers in overlapping distal areas; the method ensures at least 50 frames in common with the previous one and the following. The resultant alignment of the sub-models allows to mold strips with an overlap, at least, of 20\% (Figure 11).

The passage from the Dense Cloud to the Mesh could be a hardware limit (RAM and graphic card), because the high numbers of points in each cloud makes difficult to process the continuous information (Mesh) even for a high-end level PC.

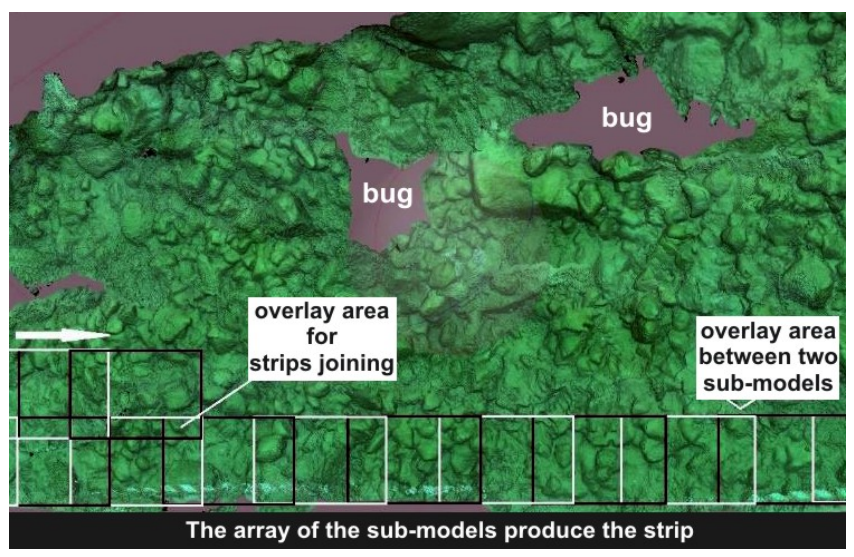

Figure 11. Overlap of sub-model Mesh and strips generation (modified from [9]).
Finally, the acquired GPS points in correspondence with the artificial and natural used markers, the ground control points (GCPs), enabled the geo-referencing of the models in a GIS environment, although the purpose of this work is not the exact location in map of the reconstructed surface, but to obtain a product that makes possible the observation of the bottom surface; for this reason, it is preferred to use the manual junction of overlapping small, but detailed sub-models, rather than have less detailed well-geo-referenced extended surfaces with many known coordinate points.

\section{RESULTS AND DISCUSSIONS}

One of the first evidence highlighted by the GeoDive method is that even the video acquisitions made under low visibility can be successively processed with success (Figure 12 and Figure 13). The 3D reconstruction results in a kind of augmented (increased) reality without the aid of adjustments in post-production (Figure 13), which allows to obtain additional environmental information that in some cases cannot be noticed by the observer, even if expert.

In the shooting conditions, used in the Albano Lake and at sea in Maratea, the Dense Cloud generated by the software, shows a great detail (Table 2); moreover, a suitable hardware would be able to distinguish objects with dimensions on the order of half a millimeter.

The success of the result obtained is not limited only to the number of points available to create the Mesh but is also due to the tracking of the pre-defined routes and keeping of low and

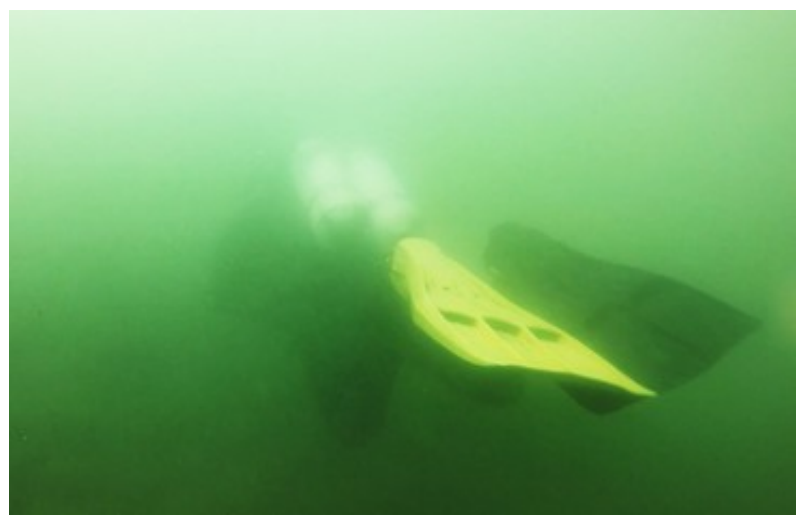

Figure 12. Real low visibility conditions in Albano Lake during some made dives.

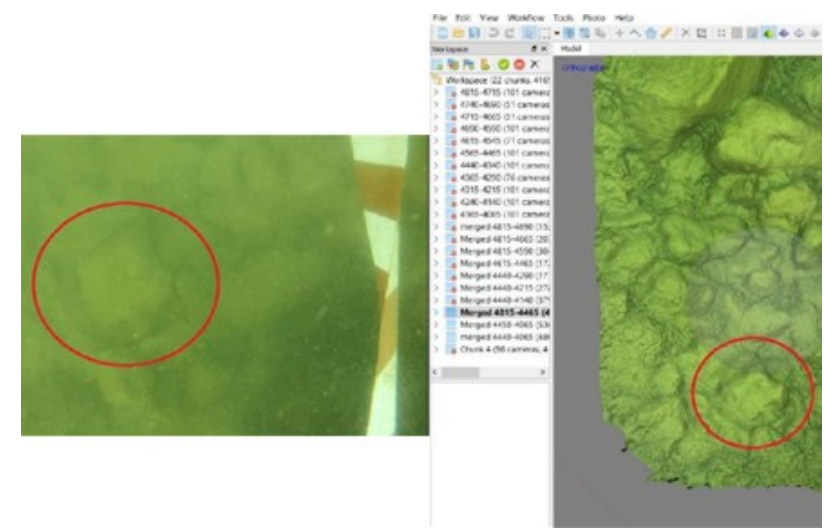

Figure 13. Comparison of subaqueous view (low contrast and low definition), on the left, and "increased reality" of the Model (high contrast and high definition on the right (modified from [9]). 
Table 2. Main 3D Models features.

\begin{tabular}{lccc} 
Parameter & Albano 1 & Albano 2 & Maratea \\
\hline Area $\left(\mathrm{m}^{2}\right)$ & 42.7 & 34.5 & 54.8 \\
Points (Dense Cloud) & 8113000 & 6555000 & 19728000 \\
Points $/ \mathrm{cm}^{2}$ & 19 & 19 & 36 \\
Ground resolution $(\mathrm{mm})$ & 0.57 & 0.57 & 0.83 \\
\hline
\end{tabular}

constant displacement speeds, to minimize the presence of bug areas in the final model, as happened in the first models made in the Albano Lake (Figure 14). The method, also tested in shallow coastal marine water with better environmental conditions, has given well results also keeping a double distance (Figure 15).

The 3D reconstructed models provided an overview of the

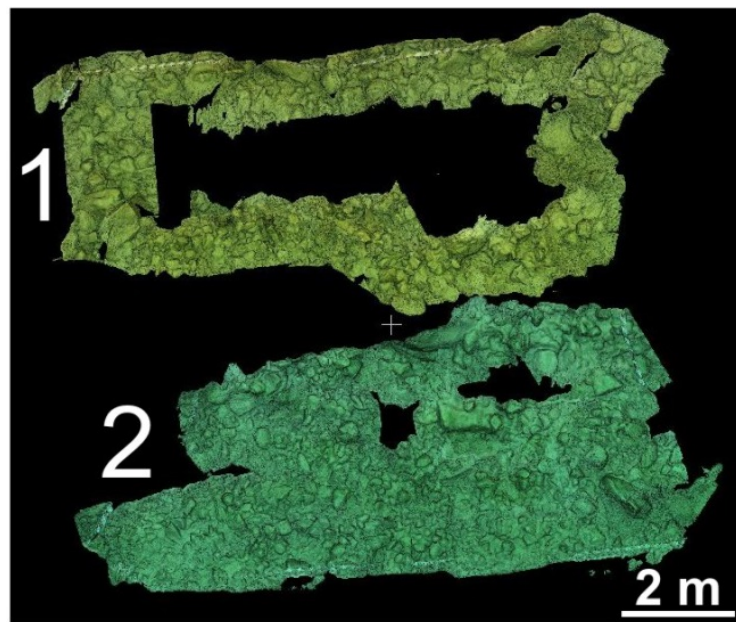

Figure 14. Albano Lake: two joined model Mesh, with bugs of different sizes (modified from [9]).

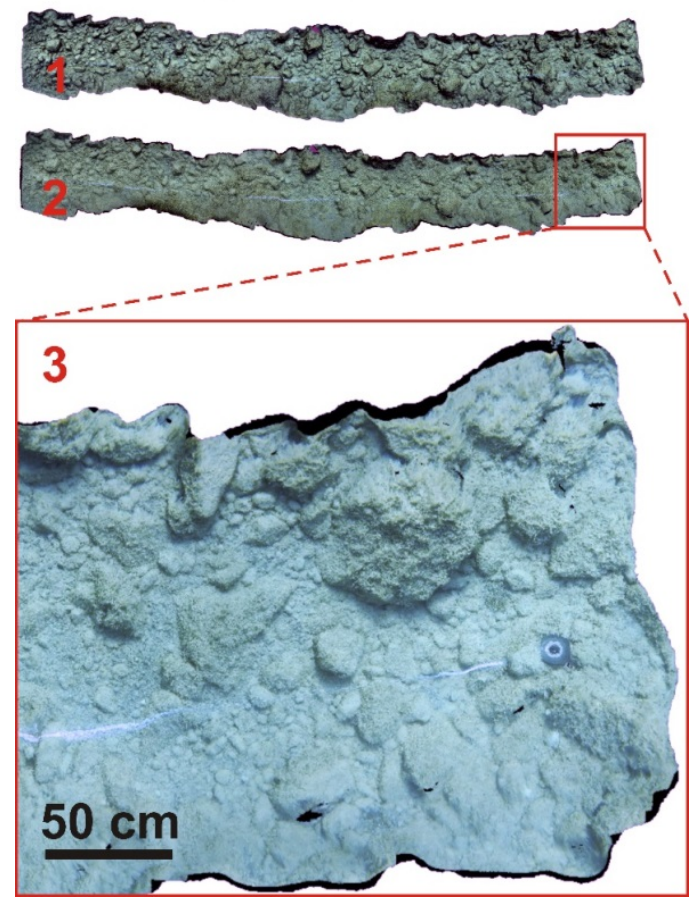

Figure 15. Maratea 3D model: 1 ) Mesh Cloud of the AB segment (length 15 $\mathrm{m})$; 2) Texture of the same segment; 3) Magnification of the right section of the texturized segment. deposits, and the basis to establish, for subsequent surveys, the location of the areas of greatest interest. Furthermore, morphometric measurements (i.e., length, areas and volumes) were performed on some blocks (Figure 16) and the results were validated by comparison with the dimensions actually measured via direct survey.

The sediments of Albano Lake are characterized by a high presence of macroscopic organic matter at all investigated depths, represented almost exclusively by plant frustules like wood and leaf fragments (Figure 17).

The results of the granulometric analysis of sediments show essentially poorly sorted sediments with sandy composition (sand range $80-83 \%$, median $82 \%$ ), with a variable amount of gravelly fraction (gravel range $9-24 \%$, median 12\%); both sand and gravel fractions are largely made up of shells of gastropods, probably the alien species Planorbella duryi [36], both whole and fragmented (Figure 18), whereas silt and clay are ever subordinates, with the silt fraction that increases with increasing depth and the clay fraction, ever low, apparently is not related to the depth (Table 3). Sample A and C, respectively the shallower and the deeper sampled, come from areas with a sparse presence of blocks and show a gravel fraction comparable and almost entirely made up by gastropods shells, while the sample B come directly from a lens of sediment

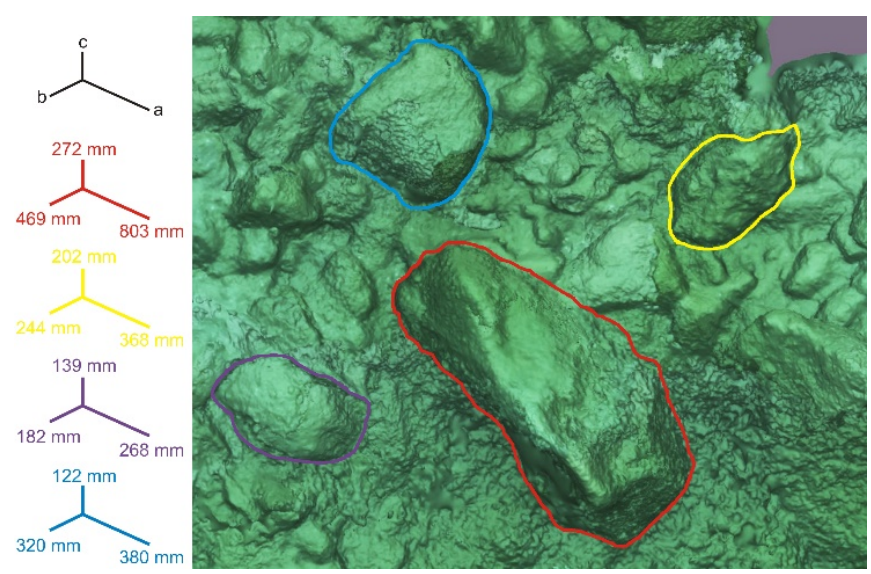

Figure 16. Some block measurements on the 3D reconstructed model of bottom of Albano Lake (modified from [9]).

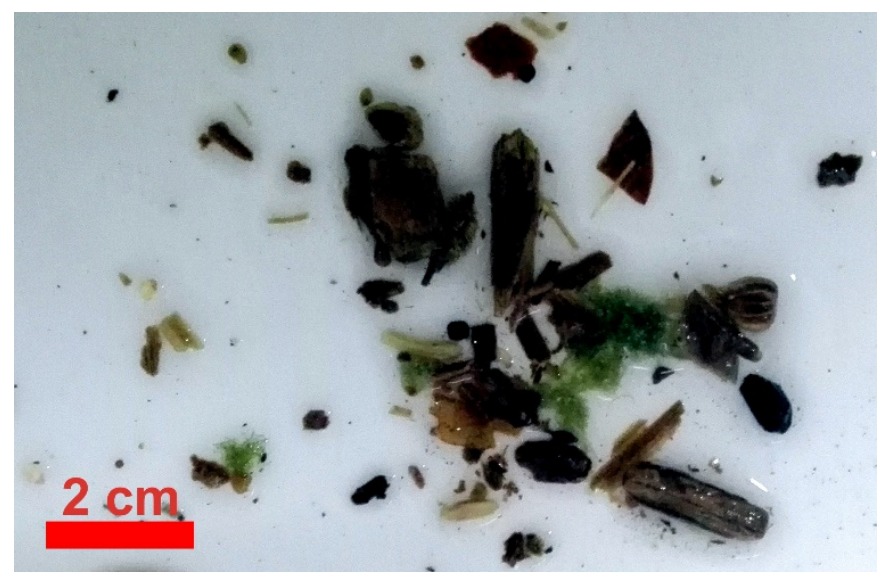

Figure 17. Albano Lake: macroscopic organic matter on the investigated sediments, represented almost exclusively by plant frustules like wood and leaf fragments. 


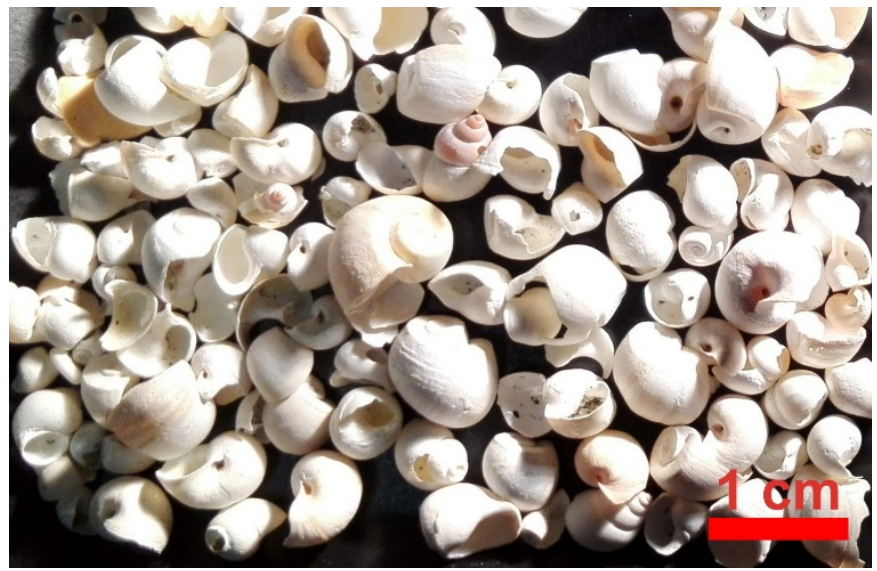

Figure 18. Albano Lake: shells of gastropods in the gravelly fraction of the sediments.

between the blocks and show the high percentage of gravel, consisting of both shells and lithic fragments.

Finally, during the performed dives in the Albano Lake, it was observed that the sediment is very mobile, (without being able to investigate whether due to the waves or currents along the bottom), because in a short time, portions of tape grid used to delimit the study area and more in contact with the bottom have been partially covered by the sediment.

\section{CONCLUSIONS}

The "GeoDive" method has allowed to reconstruct with high accuracy and a small budget 3D models of sections of submerged morphologies, as in the reported cases, consisting of debris accumulations put in place by landslides; it was possible to get a very good correspondence between the models and the real geological bodies, validated by comparison of their actual size and features.

The use of Action Sport Cam with high technical and optical performances, has allowed to have a very detailed final 3D reconstruction, which highlighted details that are not appreciable during the simple observations and video shoot.
The created models are very useful for making "dry" considerations and measurements, also for subsequent explorations and sampling. A surprising aspect of the method applied consists in its successful applicability even in low visibility conditions.

The surveys carried out in the Albano Lake with the related photographic and video acquisitions, documented, for the first time, the block field and defined its borders, allowing us to assume that the observed bottom morphology could be associated with a more recent landslide event, not yet covered by fine sediments, which partly covers the underlying reported deposit.

The sedimentological characterization of the superficial sediments of the Albano Lake block field allows us to highlight some salient features: the sediments are almost exclusively made up by sand, with a variable amount of gravel and a subordinate amount of mud, mainly formed by silt, whereas the clay is always very low. The sandy and gravelly fractions, always predominant, are made up in large percentage by shell of gastropods, both whole and fragmented.

The survey conducted in the Calaficarra pocket beach has allowed to verify the validity of the method under different environmental conditions and, at the same time, modify some of the video capture parameters to compare all the reconstructed models.

Lastly, we believe that the method developed during the scientific dives, therefore with the indispensable presence of the human operators able to make direct observations, can be validly used to characterize undetected bottom morphologies, but also to clarify and/or validate underwater morphologies, in specific points, previously reconstructed with other indirect methodologies.

\section{ACKNOWLEDGEMENT}

We want to thank Dr. Stefano Cresta of "Parco dei Castelli Romani" for allowing us to work in a restricted area of Albano Lake and all the Park workers for their assistance during the execution of scientific diving.

A special acknowledgment to Dr. Paolo Mazzanti which

Table 3. Main granulometric features of the investigated sediments of Albano Lake.

\begin{tabular}{|c|c|c|c|c|c|c|c|c|c|c|c|}
\hline Sample & Depth (m) & Gravel (\%) & Sand (\%) & Silt (\%) & Clay (\%) & $\mathrm{D}_{50}(\mathrm{~mm})$ & $\begin{array}{c}\text { Mean Size } \\
(\mathrm{mm})\end{array}$ & $\begin{array}{l}\text { Mean Size } \\
\text { (Ф) }\end{array}$ & $\begin{array}{c}\text { Sorting } \\
\text { (Ф) }\end{array}$ & $\begin{array}{c}\text { Skewness } \\
\text { (Ф) }\end{array}$ & $\begin{array}{l}\text { Kurtosis } \\
\text { (Ф) }\end{array}$ \\
\hline A & 5,3 & 12,43 & 83,45 & 3,16 & 0,96 & 0,233 & 0,325 & 1,62 & 1,86 & $-0,46$ & 1,49 \\
\hline B & 6,7 & 23,51 & 70,99 & 4,40 & 1,10 & 0,518 & 0,655 & 0,61 & 2,12 & $-0,12$ & 0,95 \\
\hline C & 11,5 & 9,16 & 82,33 & 7,54 & 0,97 & 0,140 & 0,210 & 2,25 & 1,92 & $-0,45$ & 1,25 \\
\hline
\end{tabular}

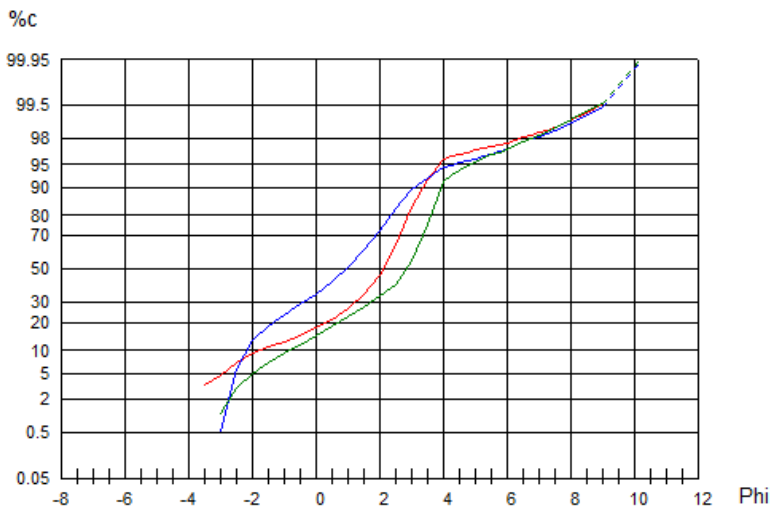

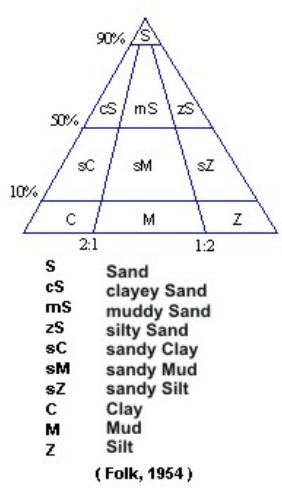

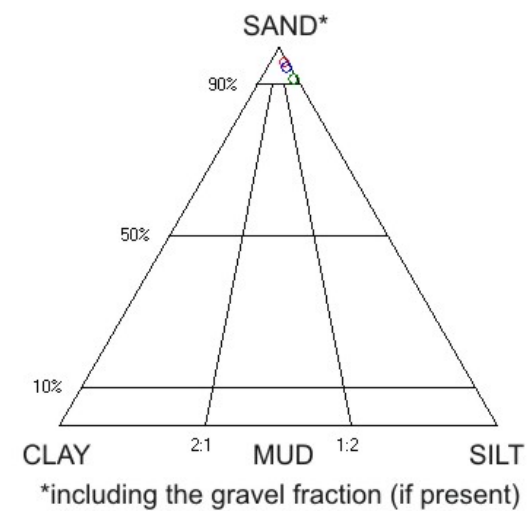


allowed us to work with a proper informatic support in Nhazca's laboratories.

We also want to thank Domenico and Luciano Quaranta of Talassa Sport of Rome for the courtesy offered during rental of underwater equipment.

Finally, we want to thank the Agisoft Company for having granted, in trial, the necessary software PhotoScan.

\section{REFERENCES}

[1] M. Anzidei, A. Esposito, "The lake Albano: bathymetry and level changes", in: The Colli Albani Volcano. R.Funiciello, G.Giordano (editors). Special Publication of IAVCEI, 3. The Geological Society, London, 2010, ISBN 978-1-86239-208-3, pp. 229-244.

[2] F. Bozzano, P. Mazzanti, M. Anzidei, C. Esposito, M. Floris, G. Bianchi Fasani, A. Esposito, Slope dynamics of Lake Albano (Rome, Italy): insights from high resolution bathymetry, Earth Surf. Process. Landforms, 34(11), (2009), pp. 1469-1486, doi: 10.1002/esp.1832.

[3] M. Anzidei, M.L. Carapezza, A. Esposito, G. Giordano, M. Lelli, L. Tarchini, The Albano Maar Lake high resolution bathymetry and dissolved $\mathrm{CO}_{2}$ budget (Colli Albani volcano, Italy) Constrains to hazard evaluation, J. Volcanol. Geoth. Res., 171(34), (2008), pp. 258-268, doi: 10.1016/j.jvolgeores.2007.11.024.

[4] P. Mazzanti, F. Bozzano, C. Esposito, "Submerged landslide morphologies in the Albano Lake (Rome, Italy)", in: Submarine Mass Movements and Their Consequences. V.Lykousis, D.Sakellariou, J.Locat (editors). Advances in Natural and Technological Hazards Research, Springer, Dordrecht, vol.27, 2007, ISBN 978-3-319-20979-1, 8 pp.

[5] M. Anzidei, A. Esposito, F. De Giosa, The dark side of the Albano crater lake, Ann. Geophys., 49(6), (2006), pp. 1275-1287.

[6] S. Furlani, F. Antonioli, T. Gambin, R. Gauci, A. Ninfo, E. Zavagno, A. Micallef, F. Cucchi, Marine notches in the Maltese islands (central Mediterranean Sea), Quatern. Int., 439(Part A), (2017), pp. 158-168, doi: 10.1016/j.quaint.2016.03.004.

[7] S. Furlani, A. Ninfo, E. Zavagno, P. Paganini, L. Zini, S. Biolchi, F. Antonioli, F. Coren, F. Cucchi, Submerged notches in Istria and the Gulf of Trieste: Results from the Geoswim project, Quatern. Int., 332, (2014), pp. 37-47, doi 10.1016/j.quaint.2014.01.018.

[8] S. Furlani, The Geoswim project: snorkel-surveying along 250 $\mathrm{km}$ of the Southern and Western Istrian Coast, AMQ, 25(2), (2012), pp. 7-9.

[9] J. Crognale, "Sperimentazione di tecniche di rilievo 3D subacqueo: applicazione ad una porzione di un deposito di frana presso il lago di Albano", master thesis in Geologia Applicata all'Ingegneria, al Territorio e ai Rischi, Sapienza Università di Roma, ("Unpublished results", 2017), 115 pp.

[10] U. Simeoni, C. Corbau, E. Pranzini, "Le pocket beach", in Le pocket beach. Dinamica e Gestione delle piccole spiagge. U.Simeoni, C.Corbau, E.Pranzini, S.Ginesu (editors). Franco Angeli ed., 2012, ISBN 978-88-204-0156-6, pp. 17-30.

[11] G. Gaglianone, Nearshore bedforms of tyrrhenian embayed micro pocket beach, Proc. of GeoSUB - Underwater Geology, Sept. 13-17, 2016, Ustica, Italy, pp. 51-53.

[12] R. Funiciello, G. Giordano, D. De Rita, The Albano maar lake (Colli Albani Volcano Italy): recent volcanic activity and evidence of pre-Roman Age catastrophic lahar events, J. Volcanol. Geotherm. Res, 123(1-2), (2003), pp. 43-61, doi: 10.1016/S03770273(03)00027-1.

[13] B. Giaccio, A. Sposato, M. Gaeta, F. Marra, D.M. Palladino, J Taddeucci, M. Barbieri, P. Messina, M.F. Rolfo, Mid-distal occurrences of the Albano Maar pyroclastic deposits and their relevance for reassessing the eruptive scenarios of the most recent activity at the Colli Albani Volcanic District, Central Italy, Quatern. Int., 171-172, (2007), pp. 160-178, doi: 10.1016/j.quaint.2006.10.013.
[14] G. Giordano, A.A. De Benedetti, A. Diana, G. Diano, A. Esposito, M. Fabbri, F. Gaudioso, F. Marasco, I. Mazzini, M. Miceli, V. Mincione, M. Porreca, S. Rodani, C. Rosa, A.P. Vinkler, E. Caprilli, S. Taviani, A. Trigari, D. Bilardello, S. Malinconico, T. Sabato Ceraldi, R. Funiciello, M. Mattei, D. De Rita, M. Parotto, R.A.F. Cas, "Stratigraphy, volcano tectonics and evolution of the Colli Albani volcanic field", in: The Colli Albani Volcano. R.Funiciello, G.Giordano (editors). Special Publication of IAVCEI, 3. The Geological Society, London, 2010, ISBN 978-1-86239-208-3, pp. 43-67.

[15] M. Gaeta, C. Freda, J.N. Christensen, L. Dallai, F. Marra, D.B. Karner, P. Scarlato, Time-dependent geochemistry of clinopyroxene from the Alban Hills (Central Italy): clues to the source and evolution of ultrapotassic magmas, Lithos, 86(3-4), (2006), pp. 330-346, doi: 10.1016/j.lithos.2005.05.010.

[16] D.M. Cruden, D.J. Varnes, "Landslide types and processes", in Landslides Investigation and Mitigation; Transportation Research Board. AK.Turner., RL.Shuster (editors). National Research Council, Special Report 247, National Research Council: Washington DC, 1996, ISBN 0-309-06208-X, pp. 36-75.

[17] S. Longhitano, Short-term assessment of retreating vs. advancing microtidal beaches based on the backshore/foreshore length ratio: examples from the Basilicata coasts (Southern Italy), OJMS, 5(1), (2015), pp. 123-145, doi: 10.4236/ojms.2015.51011.

[18] L. Carobene, G. Dai Pra, Middle and upper Pleistocene sea level highstands along the tyrrhenian coast of Basilicata (Southern Italy), Il Quaternario, 4(1a), (1991), pp. 173-202.

[19] M.R. Toccaceli, Principali elementi morfostrutturali del tratto di costa sommerso tra Sapri e la foce del Fiume Noce (Golfo di Policastro), Giornale di Geologia ser. 3a, 54(2), (1992), pp. 91 101.

[20] R. Pellicani, G. Spilotro, C.J. Van Westen, Rockfall trajectory modeling combined with heuristic analysis for assessing the rockfall hazard along the Maratea SS18 coastal road (Basilicata, Southern Italy), Landslides, 13(5), (2016), pp. 985-1003, doi: 10.1007/s10346-015-0665-3.

[21] B. D'Argenio, F. Ortolani, T. Pescatore, "Geology of Southern Apennines. A brief outline", Proc. of I.A.E.G. In. Sym. "Geology Problems in Seismic Areas", Apr. 13-19, 1986, Bari, Italy, pp. 135-161.

[22] V. Cotecchia, G. D’Ecclesiis, M. Polemio, Studio geologico e idrogeologico dei monti di Maratea, Geol. Appl. Idrogeol., 25, (1990), pp. 139-178.

[23] V. Rizzo, M. Leggeri, Slope instability and sagging reactivation at Maratea (Potenza, Basilicata, Italy), Eng. Geol., 71(3-4), (2004), pp. 181-198, doi: 10.1016/S0013-7952(03)00133-9.

[24] V. Rizzo, V., GPS monitoring and new data slope movements in the Maratea Valley (Potenza, Basilicata), Phys. Chem. Earth Parts A/B/C, 27(36), (2002), pp. 1535-1544.

[25] A. Guerricchio, G. Melidoro, Deformazioni gravitative profonde del tipo Sackung nei Monti di Maratea (Lucania), Geol. Appl. Idrogeol., 14, (1979), pp. 13- 22.

[26] F. Fiorillo, M. Limongiello, B.J. Fernández-Palacios, Testing GoPro for 3D model reconstruction in narrow spaces, Acta IMEKO, vol. 5, no. 2, article 9, September 2016, identifier: IMEKO-ACTA-05 (2016)-02-09, pp. 64-70.

[27] F.S. Rende, A.D. Irving, A. Lagudi, F. Bruno, S. Scalise, P. Cappa, M. Montefalcone, T. Bacci, M. Penna, B. Trabucco, R. Di Mento and A. M. Cicero, Pilot application of 3D underwater imaging techniques for mapping Posidonia oceanica (L.) Delile meadows, Int. Arch. Photogramm. Remote Sens. Spatial Inf. Sci., XL-5/W5, (2015), pp. 177-181, doi: 10.5194/isprsarchives-XL-5W5-177-2015.

[28] M. Mangeruga, M. Cozza and F. Bruno, Evaluation of Underwater Image Enhancement Algorithms under Different Environmental Conditions, J. Mar. Sci. Eng., 6(10), (2018), 13 pp., doi: 10.3390/jmse6010010.

[29] M. Lo Brutto, G. Dardanelli, Vision metrology and Structure from Motion for archaeological heritage 3D reconstruction: a Case Study of various Roman mosaics, Acta IMEKO, vol. 6, no. 
3, article 6, September 2017, identifier: IMEKO-ACTA-06 (2017)-03-06, pp. 35-44.

[30] Y. Onmek, J. Triboulet, S. Druon, A. Meline, B. Jouvencel, "Evaluation of Underwater 3D Reconstruction Methods for Archaeological Objects: Case Study of Anchor at Mediterranean Sea", Proc. of 3rd Int. Conf. on Control, Automation and Robotics, Apr. 24-26, 2017, Nagoya, Japan, pp. 394-398.

[31] G.R.D. Bernardina, P. Cerveri, R.M.L. Barros, J.C.B. Marins, A.P. Silvatti, In-air versus underwater comparison of 3D reconstruction accuracy using action sport cameras, J. Biomech., 51, (2017), pp. 77-82, doi: 10.1016/j.jbiomech.2016.11.068.

[32] G.R.D. Bernardina, P. Cerveri, R.M.L. Barros, J.C.B. Marins, A.P. Silvatti, Action Sport Cameras as an Instrument to Perform a 3D Underwater Motion Analysis, PLoS ONE, 1(8), (2016), 14 pp., doi: 10.1371/journal.pone.0160490.

[33] F. Menna, E. Nocerino, S. Del Pizzo, S. Ackermann, A.
Scamardella, "Underwater photogrammetry for 3d modeling of floating objects: the case study of a 19-foot motor boat", Proc. of 14th Congress of Intl. Maritime Association of Mediterranean (IMAM 2011), Genova, Italy, 2011, 8 pp.

[34] G. Gaglianone, "Caratterizzazione sedimentologica, produzione carbonatica e fattori di controllo dei substrati colonizzati da praterie a fanerogame marine nel Mediterraneo Occidentale", $\mathrm{PhD}$ thesis in Earth Science, Sapienza Università di Roma, ("Unpublished results", 2013), $352 \mathrm{pp}$.

[35] G. Gaglianone, M. Brandano, G. Mateu-Vicens, The sedimentary facies of Posidonia oceanica seagrass meadows from the central Mediterranean Sea, Facies, 63:28, (2017), 21 pp., doi: 10.1007/s10347-017-0511-2

[36] S.W. Alexandrowicz, Planorbella duryi (Wetherby, 1879) from the crater-lake Albano (Central Italy), Folia Malacol., 11(3/4), 2003, pp. 89-93. 